\title{
The Historic Centre in Spanish Industrial and Post-Industrial Cities
}

\author{
Jesús M. González Pérez ${ }^{*}$ and Rubén C. Lois González² \\ ${ }^{1}$ Departament of Earth Sciences, Guillem Colom Bulding, University of the Balearic Islands, Spain \\ ${ }^{2}$ Department of Geography, Faculty of Geography and History, Pza. Universidade 1., University of Santiago de \\ Compostela, Spain
}

\begin{abstract}
The congestion of the city area within the walls along the 19th century and the economic and social crisis of historic centres during most of the 20th century led to their deterioration. The theoretical conceptualization and practical implementation of domestic improvement and reform programmes have changed with time. With the beginning of the new century, urban dynamics in a globalized space are making historic places into real scenes for economic exploitation related to massive and residential tourism with a cultural brand design, as well as to property for well-to-do population. As a consequence, the social component took a secondary place in town planning theory. In this context, our essay is aimed at studying the response of town planning to the recovery of a historic city fully sharing the dynamics of a postmodernist and global metropolis.
\end{abstract}

Keywords: Historic centre, suburbanization, urban restoration, spatial segregation, immigration.

\section{INTRODUCTION}

In the last few decades, the structure and morphology of the Spanish city have undergone dramatic changes. Spatial processes from the Anglo-Saxon world have an influence on the building of the contemporary Spanish city. In the global information society, film images of shopping malls, crowds in edge cities or theme parks are the best publicity for the building of these new urban landscapes [1], which are a reality in almost every city. The dense city developed until the 70's was followed by a dispersed city built with new elements from counterurbanization and suburbanization. The city organized around its heritage and the centrality of the pre-industrial city were followed by a new kind of city promoted by means of large heritage containers which -in too many ocasions- can even hide the importance and quality of the old town.

In such a situation we wonder if a resident of Bilbao can feel more identified with the whole postmodern landscape built around the Guggenhaim Museum than with the Casco Viejo (historic core of the city) or the interesting 19thcentury Ensanche de Población (urban extension). Or if someone from Valencia boasts more about Santiago Calatrava's architecture (City of Arts and Sciences) than about the architecture in the Ciutat Vella (old town) and its extensive monumental heritage. It is not easy to answer these questions with certainty. In a way it could be so, but we must not forget that new architecture sectors are no more than leisure and shopping areas, mostly located in the outskirts not in the case of Bilbao-, usually without a district structure and therefore places where no social relations exist. This is precisely a kind of relation easy to find in the dense and

*Address correspondence to this author at the Departament of Earth Sciences. Guillem Colom Bulding. University of the Balearic Islands, 07006 Palma de Mallorca, Spain; Tel: +34-971172380; Fax: +34-971173184;

E-mail: jesus.gonzalez@uib.es central city of the pre-industrial period (historic centre) and the first pre-industrialization (urban extension). In these conditions, the present historic city took on the principles of urban and intraurban competition in terms of tourism, leisure, business, population, cultural events, etc.

The analysis of the 21 st-century historic city is dealt with from a double point of view. Firstly, the analysis of the physical, social and landscape consequences of comprehensive town planning and restoration along the last three decades. In order to do this, a comparison is made on the evolution of intervention policies in historic centres, from the 19th-century renovation actions up to the allembracing restoration carried out since the 80 's. Secondly, the analysis of the resulting processes will help us understand some of the most important socio-territorial dynamics developing in the historic centre as a product of the present city. Specifically, the place of spatial organization in the current city, as competition or complement to the new urban areas resulting from suburbanization processes.

\section{SUBURBANIZATION VS GENTRIFICATION IN THE SPANISH CITY}

A first thought about historic centres in the Spanish city arises from analyzing its position in a new city model which favors suburbanization and an extensive low-density residential growth. A city progressively leaving behind its dense structure. It is here where the historic centre plays a vital role in the spatial distribution of the city -as regards leisure and tourism, economy and civil service, shops and restaurants, heritage and culture, social relations and sense of belonging, etc.

Spain is known for its highly dense and compact towns. The urban centres of Spanish metropolitan areas are densely populated. Spain is the third EU country with the highest urban population density, being Spanish metropolitan areas among the most populated in Europe. However, in a context 
of dramatic growth of its housing stock, Spain's opening-up to democracy also had an effect on the import of AngloSaxon spatial and residential models. Thus, the compact feature of the city has been going backwards since the 80 's, when a new time began in Spain's development process defined by Peter Hall [2] as the middle stage between suburbanization and deurbanization. $73.20 \%$ of residential buildings built in 2005 are one-family units and $62.35 \%$ of all those for residential use where terraced ones.

In many American large cities, there has been a constant decline of residential urban centres since the end of the II World War. In most of Europe there is a spatial contradiction between the historic centre and the suburbs. In Spain, the ocurrence of suburbs should not always be related to the decline of historic centres. What is more, the origin of suburbanization coincided in time with the interest in recovering genetic cities -as two independent and apparently unrelated phenomena. In other words, the thriving of periurban and suburban districts took place particularly in the 80 's, while the first democratic administrations focused their efforts on the social and heritage recovery of an old and seriously endangered historic town. All in all, there seems to exist an inside-outside duality in our city -the generalization of more selective gentrification processes occurs simultaneously with other demographically more important counterurbanization processes.

In view of this spatial duality, historic cities are either competing in resources and functional-residential attraction with new areas developed to host the suburban society, or adapting themselves and taking part in this business-city mainly through leisure, tourism and second residence.

The territorial and population processes taking place in the metropolitan area of Barcelona are a good example to study such a duality. Given its metropolitan condition and its tourist-residential function, this area is threatened by a deep extension of low-density development. In 1972, around 215 $\mathrm{km}^{2}$ of Barcelona's metropolitan area were fully built-up. In 2004, the built-up area exceeded $500 \mathrm{~km}^{2}$. However, while the settling is spreading out and the population is scattering, the different centres are recovering their old demographic and real state dynamism. The Eixample de Cerdá district is the economic, financial and social centre of the city, but the pre-industrial historic centre seems to be regaining its prominent role as well. In a word, suburbanization is compatible with gentrification.

The Ciutat Vella district is one of the ten districts making up the municipality of Barcelona. As its name indicates, it includes the historic city itself -Barceloneta, Parc, Gótic and the Raval quarters. The maps below (Fig. 1) show the unquestionable demographic and economic dynamism of the historic centre, much higher than that of other more populated and tertiary districts. The evolution of the sale price of housing and planning permissions are signs of gentrification in some quarters of the Ciutat Vella. Despite this, if gentrification is limited to the entry of middle-class population and substantial economic resources, we think that it can only be talked about resettlement of the historic centre. The continuous demographic growth is mainly due to the arrival of immigrants. In 2006, foreigners made up $38.5 \%$ of the district's population.

The processes taking place in the Ciutat Vella are also taking place in other historic centres of Spanish cities. First, the population rises owing to the arrival of immigrants looking for cheap housing. Later -but much slower- it grows due to the settlement of middle and high-class young people looking for a primary or secondary residence. The increase

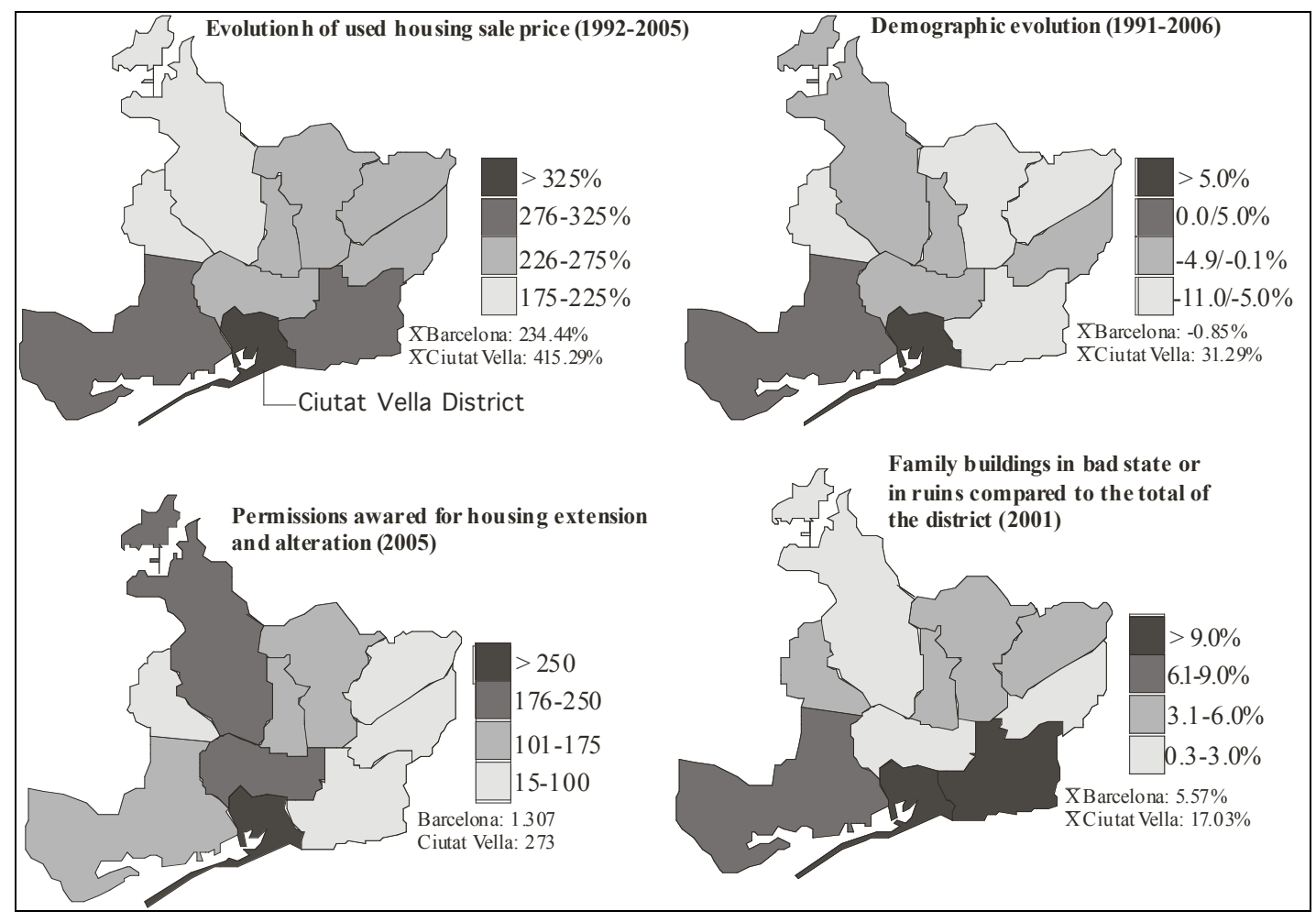

Fig. (1). Population and housing in Barcelona's urban districts. Source: self-made from statistics of the town council of Barcelona. 
in the price of housing in historic centres -particularly as a result of land speculation- is a good indicator of the interest they arouse for resources and important domestic and foreign investors, who are aware of the new functionalities of these quarters.

The existence of important elements of social exclusion within the Spanish city confirms what Borja y Castells [3] define as intrametropolitan dual city. Without being organized or even without being seen, the most appreciated functions coexist with the most degrading ones in the same city or even in the same quarter, and the ruling classes with the most underprivileged ones. There are significant residential movements of middle-class young population towards the periurban area, while the historic city appreciates its centrality as residential area for middle and high classes and top-quality business.

\section{HISTORIC CITIES RESTORATION CULTURE AND POLICY}

The historic city is identified with an urban fabric sector of great historical and symbolic value originated in preindustrial times. Its most important development started in the Middle Ages (11th century) and went on until the beginning of the transformations caused by the 19th and 20th-century Industrial Revolution. Variable in origin, form and size, the historic city is the initial core of the present city. It is usually identified with the area within the city walls, coinciding nowadays with the old and monumental city areas. Its architectural wealth makes it into the most representative area of the city, but also an important sector of the city centre, as it behaves as a container of economic, symbolic and artistic values.

In Spain, the usual equivalence between historic city and pre-industrial city has been progressively overcome. Its definition has changed from a monumental and pre-industrial perception to a morphologic and atemporal appraisal. Among new spaces are those of great historic and architectural value appeared during the industrial period. This is especially the case of working-class surburbs born during the Industrial Revolution, urban extensions of the second half of the 19th century, certain quarters of garden city and others with state-subsidized housing built in the first decades of the 20th century (Table $\mathbf{1}$ ).

\section{THE BEGINNING OF THE INTERNAL FRAGMENTATION OF THE HISTORIC CENTRE: 19TH-CENTURY RENEWAL STRATEGIES}

The congestion and deterioration of cities in the beginning of the industrial period was solved differently in Spain and most European countries. An internal reform was the most widespread solution in Europe, especially from the initiatives carried out in Paris and Viena. In Spain, the tastes of the bourgeoisie and the lack of laws which made confiscation easier resulted in the city and town planning being projected towards the outside of the walls (Fig. 2). Thus, legislation on urban extension -drawn up from Ildefonso Cerdà's exceptional theoretical work and wellknown plan- turned into a replica of Haussmann's reform model, which was becoming a paradigm in Europe [4]. In regulations on open requests for tenders to draw up urban

Table 1. The Pre-Industrial Historic City in the Town-Planning Legislative Context of the Industrial Urban System

\begin{tabular}{|c|c|c|c|}
\hline Urban Laws & General City Model & Situation of Historic Centres & Historic Centre Planning Proposal \\
\hline $\begin{array}{l}\text { Confiscation Decrees on } \\
\text { Religious Orders (1835-1836) }\end{array}$ & $\begin{array}{l}\text { Fortified city. } \\
\text { Evolution from conventual to } \\
\text { bourgeois city. }\end{array}$ & $\begin{array}{l}\text { Centrality. } \\
\text { High demographic and building densities. } \\
\text { Urban congestion and deterioration. }\end{array}$ & $\begin{array}{l}\text { Reuse of confiscated religious } \\
\text { constructions as public buildings. } \\
\text { Creation of squares and public } \\
\text { areas. }\end{array}$ \\
\hline $\begin{array}{l}\text { Town Geometrical Plans } \\
\text { (1846) }\end{array}$ & $\begin{array}{l}\text { Fortified city: fortified towns. } \\
\text { Appearance of poor quarters } \\
\text { outside the city walls. }\end{array}$ & $\begin{array}{l}\text { Centrality. } \\
\text { High demographic and building densities. } \\
\text { Urban congestion and deterioration. }\end{array}$ & $\begin{array}{l}\text { Uniform and radical streetline } \\
\text { system. }\end{array}$ \\
\hline $\begin{array}{l}\text { Acts on Urban Extension } \\
\quad(1864,1876,1892)\end{array}$ & $\begin{array}{l}\text { Walls demolition. } \\
\text { City expansion outside the walls } \\
\text { through an urban extension. }\end{array}$ & $\begin{array}{l}\text { Loss of centrality. High densities. Urban } \\
\text { congestion and deterioration. Coexistence } \\
\text { of social groups (bourgeoisie and } \\
\text { immigrant working-class population). }\end{array}$ & $\begin{array}{l}\text { Exclusion of any kind of intervention } \\
\text { in the area within the city walls. }\end{array}$ \\
\hline $\begin{array}{c}\text { Sanitation and Internal } \\
\text { Improvement in Large Cities } \\
\text { (1895) }\end{array}$ & $\begin{array}{l}\text { Urban extensions under } \\
\text { construction. } \\
\text { Spread of poor quarters in } \\
\text { industrial cities. }\end{array}$ & $\begin{array}{l}\text { High densities. Urban congestion and } \\
\text { deterioration. }\end{array}$ & $\begin{array}{l}\text { Sanitation services, urban } \\
\text { beautification, demolition and } \\
\text { rebuilding ex novo, opening of } \\
\text { traffic arteries (major roads). }\end{array}$ \\
\hline Municipal Statute (1924) & $\begin{array}{l}\text { City model }=\text { historic centre }+ \\
\text { urban extension }+ \text { peripheral } \\
\text { poor quarters }+ \text { social-housing } \\
\text { groups }\end{array}$ & $\begin{array}{l}\text { Loss of centrality. Urban deterioration. } \\
\text { Most social groups are underprivileged. }\end{array}$ & $\begin{array}{l}\text { Sanitation services, demolition and } \\
\text { rebuilding ex novo, opening of } \\
\text { traffic arteries (major roads). }\end{array}$ \\
\hline $\begin{array}{l}\text { Land and Urban Planning } \\
\text { Law (1956) }\end{array}$ & $\begin{array}{l}\text { A city where development is } \\
\text { encouraged. } \\
\text { Major social housing actions. } \\
\text { The city grows further than } \\
\text { planned. }\end{array}$ & $\begin{array}{l}\text { Loss of centrality. Loss of economic } \\
\text { functions. Population decrease. Urban } \\
\text { deterioration. }\end{array}$ & $\begin{array}{l}\text { The Special Plan. In practice, only } \\
\text { monuments are protected. } \\
\text { Pedestrianization of streets within } \\
\text { city the walls. }\end{array}$ \\
\hline
\end{tabular}



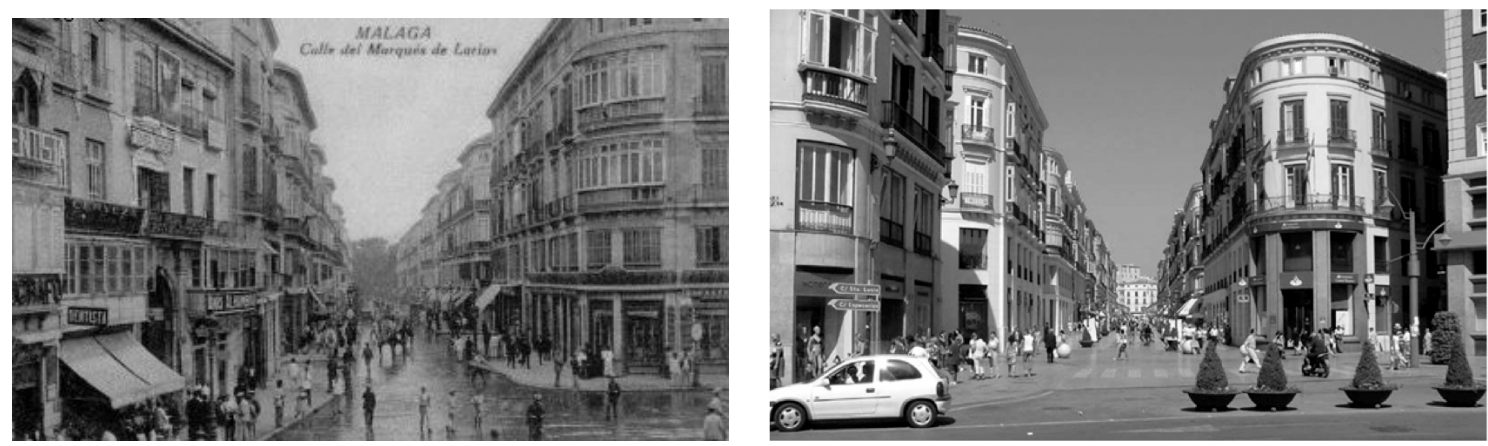

Fig. (2). Historic and present pictures of Larios street, Malaga, opened between 1887 and 1891 as a major road (Gran Vía). source: postcard and self-made.

extensions, it was expressly mentioned that the city within the walls had to stay out of the new urban planning. Such obligations of general procurements contributed to the progressive decay of historic cities.

As the nineteenth century progressed, the preindustrial city increased its compactness and its densification. In general, the preindustrial cities had serious hygienic and functional problems, related to the overcrowding and the absence of modern urban services [5]. Almost every Spanish city approved urban extensions during the second half of the 19 th century and the beginning of the 20th century. But the pre-industrial city also changed due to town-planning proposals which varied in depth and significance. The first was related to the successive laws considered since 1820 directed to the confiscation (desamortización) of church property. In the new parcels result of the demolition of the religious buildings dominated the regular forms (plots and apples). The bourgeoisie and the popular classes occupied the confiscated spaces [6]. Secondly is the Plano Geometrico de Poblaciones (1846), which is the first regulation of the contemporary era on the regulation and ordering of urban space in Spain. Their proposals are simple instruments for the protection of the public dominion and suppose a minimum limitation of the property right [7].

Finally, la Ley de Saneamiento y Mejora Interior de las Grandes Poblaciones (1895), that it is the primera law de carácter higienista aprobada en España. Although we do not share the idea totally, some authors arrive to relate its proposals with the policy of urban renovation initiated by Haussmann in Paris [8]. The Law of 1895 aimed at improving the life conditions of a pre-industrial city which was unable to adapt to the transformations and residential needs required by the industrial city. Along with the necessary sanitation works, the Spanish city entered a new period of urban beautification, reflected on the improvement of the traffic and representative system. The demolition of degraded areas and the rebuilding ex novo was the most widespread solution -being ist main goal to increase the added values created by the use of urban land. Therefore, the pre-industrial city -in the hands of the new industrial bourgeoisie- split in two: the modern and appreciated city, progressively filled with elegant high-class buildings; and the old and degraded one, where the industrial proletariat of rural origin lived. This breach can be seen since the opening of major traffic arteries which -unless already a fact in some cities since the mid-19th century- became the main internal reform action. Known as "Gran Vía" (major road), this urban surgery contributed to increase the value of restored and rebuilt areas (Fig. 3). Meanwhile, behind these new and elegant buildings, the rest of the historic city was becoming isolated and deteriorated.

In short, the 19th-century Spanish city was projected towards the outside by means of expansion plans. However, it has also been able to look at European influences and has planned internal reforms of different intensity, similar to the French percements or the Italian sventramenti. In general, such town-planning projects and socio-territorial structure did not change in the Spanish city within the walls almost until the 1980's. Owing to this, the present post-industrial historic city preserves - as for internal planning- most of the processes of the industrial city.

\section{THE LEADING ROLE OF THE URBANIST LEFT AND THE INFLUENCE OF THE BOLOGNA MODEL}

After an original and proactive urban planning during the 19th century, a long period with few innovations went on until 1980. With the 1924 Municipal Statute, the city expansion kept on being carried out through urban extensions, and the internal reform resorted to demolition and rebuilding actions, with traffic actions gaining in importance. As a result, the building of major roads -as wide visual axis- still divided the Spanish city within the walls during the first half of the 20th century (Fig. 4).

The law which was the origin of the Spanish Urban Development Law (1956 Land Law) regulated for the first time a planning figure (the Special Plan) exclusively aimed at protecting and preserving singular (urban and rural) spaces. But most town councils were completely unconcerned about this. During General Franco's militar dictatorship, historic centres were struggling with neglect, destruction through renovation policies similar to those implemented at the end of the 19th century -but worsened by the existence of new techniques and building materials- and, at the very best, their protection as National Historical Complexes. The last possibility, although ruled by scarcely or not at all comprehensive monumentalist principles, was the best measure for preserving the most notable architectural heritage.

In Spain, methodological restoration principles appeared in the beginning of the post-industrial period (at the end of the 70's) due to the spread of Italian restorarion's town planning, which was focused on the "Bologna model". The 

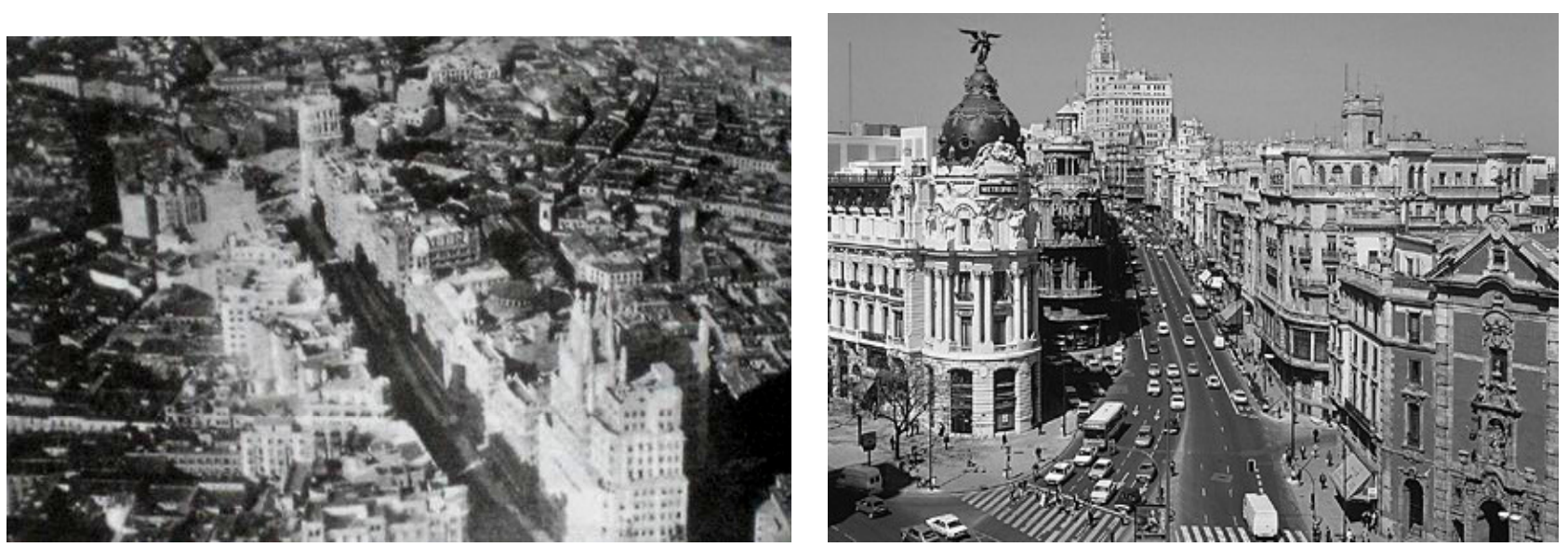

Fig. (3). Pictures of Madrid's gran vía in 1930 and 2006. Source: [9] and self-made.

ideology and works of the group self-called La Tendenza (directed by Aldo Rossi) reflected in the Bologna Plan (1971) had an extraordinary influence on a small -though excellent- generation of Spanish town planners and politicians of the second half of the 70's.

The deteriorated condition of Spanish historical cities in the beginning of the 80's confirms Gabrielli's idea [11] that rehabilitation -as urban re-exploitation- is a product of crisis. The strategies planned during the first years of democracy were developed preserving some common features. On the one hand, the interest in restoration from all-embracing points of view was an exclusive goal of town councils governed by the left. New town councils blamed the predemocratic plan for all urban problems, which gave priority to the drawing up of new more democratic and participatory instruments with an emphasis on social goals -adapted to the 1976 Revised Land Law Text. The new municipal councils ruled by the left met neighbors' demands and focused on solving big shortfalls in equipment, transport housing development and services [12]. Some councils -particularly when the Town Planning Councilorship was held by the Spanish Communist Party (PCE)- laid the foundations to recover and revitalize the historic city through town planning, rehabilitation and heritage policies [13]. On the other hand, significantly conservationist social and historiccultural arguments characterized the rationality of restoration interventions. This was the case of e.g. the Internal Reform Special Plan (IRSP) for El Puig de Sant Pere, Palma de Mallorca. Drawn up in 1980, this was the first IRSP for a historic centre passed in Spain (Fig. 5).

The methodology established through the implementation of the new Historical Heritage Law (1985) and special planning produced extraordinary results in Spanish urban restoration: centrality, defense of historic-cultural, economic and social values; housing market boost, strategies to reuse what was already built, giving value to public areas, etc. All in all, the Spanish urban restoration era began in the end of the 70's, when a radical change in urban policies included an

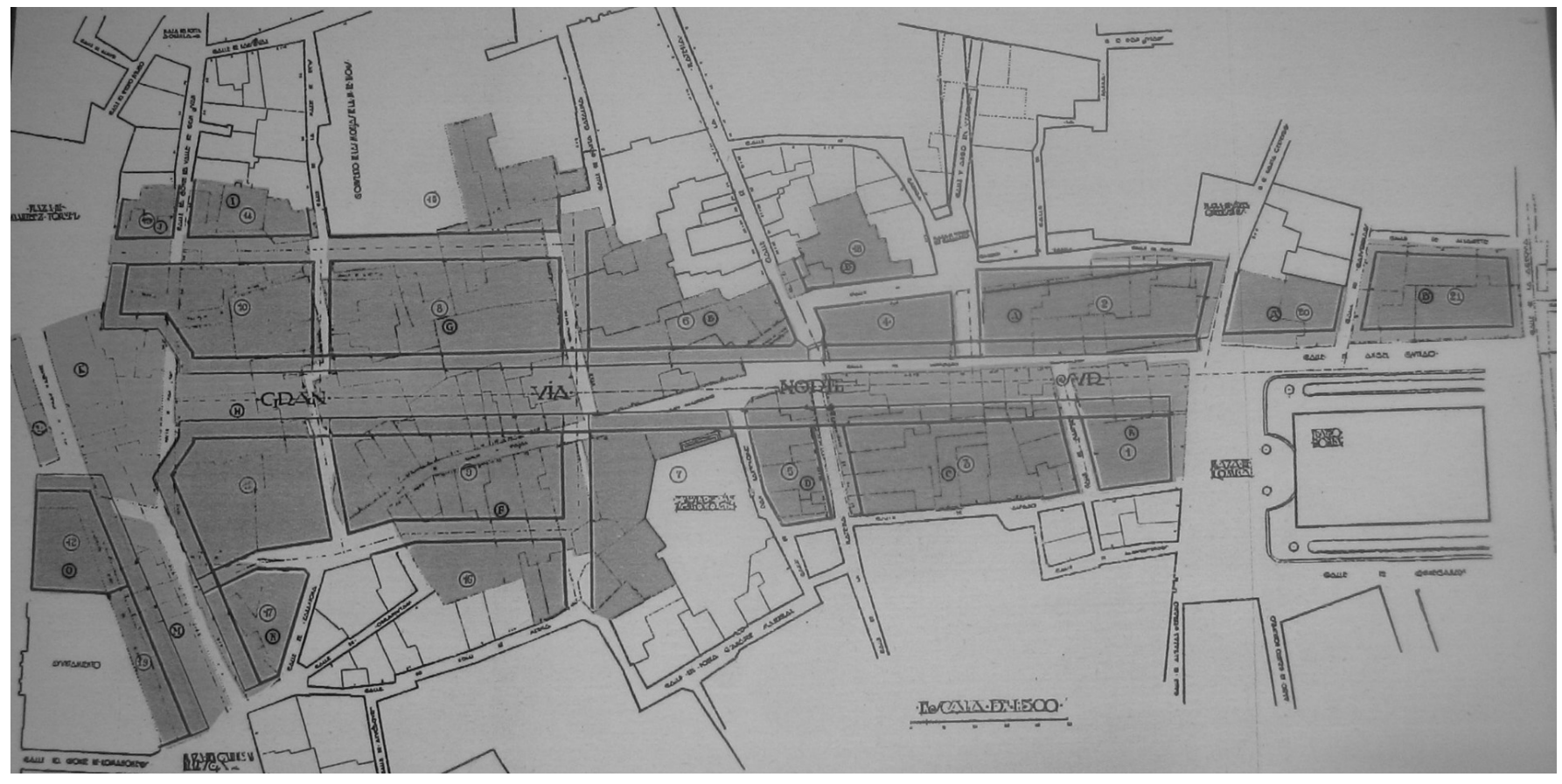

Fig. (4). Major road proposal in the reform, extension and sanitation project of the city of Murcia (1928). source: [10]. 

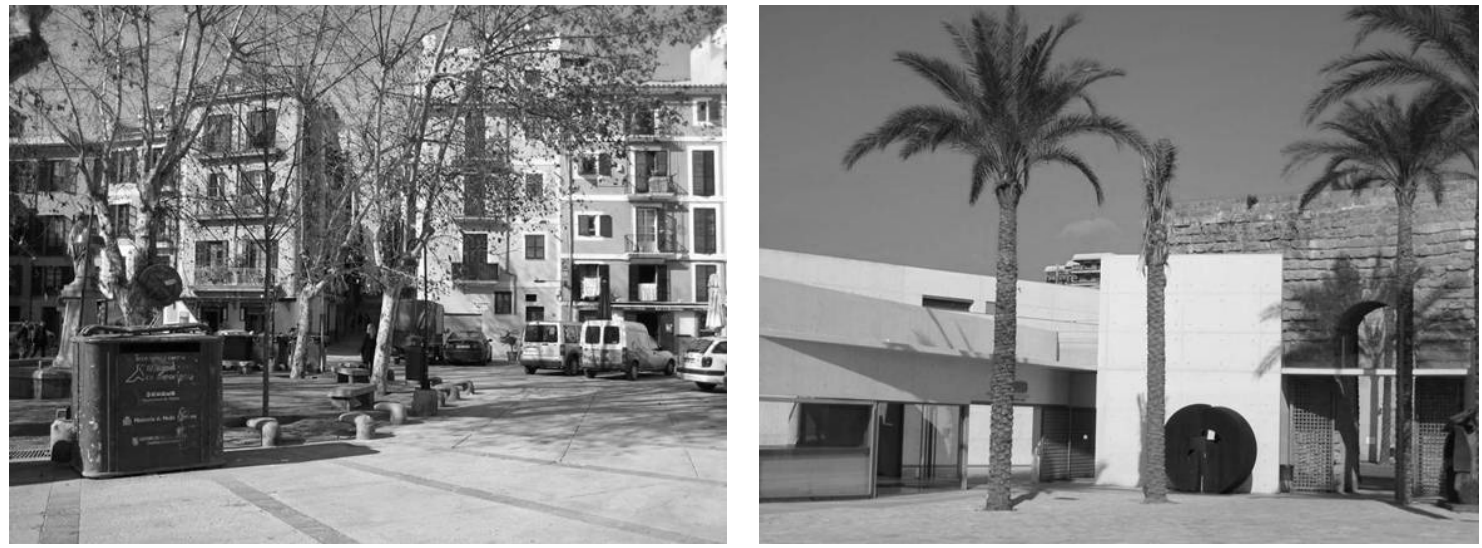

Fig. (5). Equipment and public areas recovered in the muslim-origin quarter of El Puig de Sant Pere, Palma de Mallorca. Source: self-made.

interest in the rehabilitation of the existing city, although we should not forget it- without leaving behind strategies to create a new city. At that time the focus was mainly on public investment in improving the built-up heritage and the residents' social conditions. This was undoubtedly a technical step forward, but we would dare say that this progress was above all political and democratic. From 1990, the fact that new values were accepted -such as centrality, new social tastes, the prevalence of the "unquestionable" neoliberal economic model and possibilities opened to cultural and urban tourism- led to the development of intervention theories until rehabilitation was understood as business.

\section{THE HISTORIC CENTRE AS PRODUCT AND ITS COMPETITIVENESS LEVEL IN THE POSTMODERNIST AND GLOBAL CITY}

On another occasion, we had the opportunity to write that the historic centre is one of the main spaces where the 19th and 20th-century urban theory and reality may be observed [14]. Nowadays it is difficult to guess if the same will happen in the 21 st century. But we can assert that the historic centre of the beginning of this century is witness to all of the changes that the post-industrial city is undergoing -firstly in its postmodernist aspect and more recently in its global version. The success of special planning in Spanish historical cities is outstanding (Table 2). However, with an aim to saving the genetic city from crisis and deterioration, most contents of such planning have excluded all-embracing goals and are now focused on a city model understood as a real buying enclave, specialized in postfordist activities. The fashionably gentrificated enclaves of urban centres are becoming spaces powerfully rebuilt by the marketing industry, which is turning them into idyllic spaces where the most varied life-style dreams can be made into reality [15]. Only the foreign population with less means of support escapes this functional logic planned by administrations and investors, as it still settles in cheap-housing quarters not yet restored. As a result, this population is segregated in guettos (Fig. 6).

\section{THE HISTORIC CENTRE IN THE GLOBAL CITY: NEW TOURIST-RESIDENTIAL FUNCTIONALITIES AND SCENERY CREATION}

From Urban Restoration Pilot Studies -implemented during the first post-Franco democratic government- up to the consolidation of the Urban Programs $\ddot{y}$, the qualitative $\ddot{y}$ la forward in the Spanish historic centre recovery policy has been of great importance. In 2007, there are 875 complexes classified as historical monuments. In accordance with the legislation on Heritage currently in force (1985), once a complex has been declared as historical, there is an obligation to draw up and pass a special plan -a territorial plan characterized by its flexibility and adaptability to include sectorial goals [16]. All town-planning laws passed by the Autonomous Communities provide for a figure of this kind. As a complement, the Spanish Royal Decree 2.329/1983 regulates the Areas of Integrated Rehabilitation.

In other essay we studied the main tertiary specializations of historic cities, focusing particularly on the relationship they establish with tourism [17]. In Spain there are interesting works which analyze the impacts of tourism on built heritage or urban environment [18-20]. Some strategic lines of the Urban initiatives I and II helped promote activities related to tourism and leisure. Tourism has always been a vital strategic line in the cities declared World Heritage. Actually, the declaration of World Heritage of a certain city represents itself an strategic action of inestimable value. From the very day of this declaration, the city becomes a consumer product: a place to visit and where to invest (Fig. 7). Although mechanisms were progressively introduced to regulate tourist host capacity, this economy sector keeps on gaining in value as the most suitable for the economic exploitation of the eleven Spanish historic cities awarded with this important distinction by the planning.

The demographic "leakage" can have negative consequences for any historic centre, but its residental habilitation could be even more disadvantageous. The rise in land prices in the historic centre of Salamanca, Santiago de Compostela, Palma de Mallorca, San ÿ Sebastián, Seville or Barcelona $\ddot{y}$-among many other cities- makes it difficult for 
Table 2. The Pre-Industrial Historic City in the Town-Planning Legislative Context of the Post-Industrial Urban System

\begin{tabular}{|c|l|l|l|}
\hline Urban Laws & \multicolumn{1}{|c|}{ General City Model } & Situation of Historic Centres & Historic Centre Planning Proposal \\
\hline \hline $\begin{array}{c}\text { 1975 Reform of the Land Law } \\
\text { (TR1976) }\end{array}$ & $\begin{array}{l}\text { Crisis of the industrial city and } \\
\text { models encouraging } \\
\text { development. }\end{array}$ & $\begin{array}{l}\text { Loss of centrality. Loss of economic } \\
\text { functions. Population decrease. } \\
\text { Urban deterioration. }\end{array}$ & $\begin{array}{l}\text { More heritage protection awareness. First } \\
\text { comprehensive rehabilitation proposals } \\
\text { (Special Plan). The “urbanist left": social } \\
\text { and conservationist }\end{array}$ \\
\hline $\begin{array}{c}\text { 1990 Reform of the Town- } \\
\text { Planning System and Land } \\
\text { Valuations (TR1992) }\end{array}$ & $\begin{array}{l}\text { Return to urban soil. } \\
\text { Suburbanization and } \\
\text { metropolization. }\end{array}$ & $\begin{array}{l}\text { Generalization of rehabilitation. } \\
\text { Coexistence of revitalized central } \\
\text { quarters with decayed red-light } \\
\text { districts. New guettos as a result of } \\
\text { social problems (drug sale and } \\
\text { use). }\end{array}$ & $\begin{array}{l}\text { Inclusion of neoliberal town-planning } \\
\text { practices. New functionalities. Tourism. } \\
\text { Structural funds and EU initiatives } \\
\text { (Urban). }\end{array}$ \\
\hline $\begin{array}{l}\text { 1998 Reform of Land } \\
\text { Regulation and Valuations }\end{array}$ & $\begin{array}{l}\text { Suburbanization and } \\
\text { metropolization. Population rise } \\
\text { in urban centres: immigration. }\end{array}$ & $\begin{array}{l}\text { Generalized rehabilitation. } \\
\text { Fragmented historic city. Tourist } \\
\text { saturation and monoculture } \\
\text { problems. The historic city } \\
\text { undergoes all the processes of the } \\
\text { global city. }\end{array}$ & $\begin{array}{l}\text { Rehabilitation is extended to industrial } \\
\text { historic centres. New regional legislative } \\
\text { and planning instruments. First } \\
\text { sustainability attempts. }\end{array}$ \\
\hline
\end{tabular}

Source: self-made.

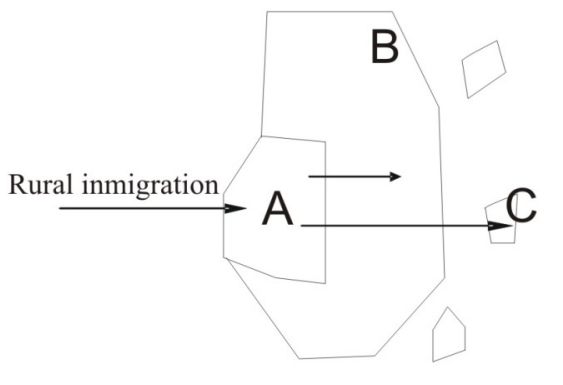
URBAN STRUCTURE AND INDUSTRIAL CITY (I)
$(1850-1930)$

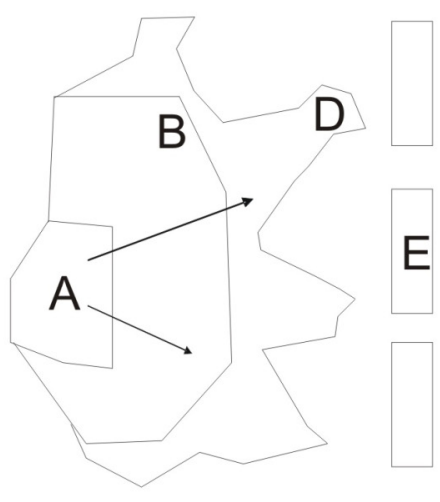

URBAN STRUCTURE AND POSTINDUSTRIAL CITY (I) $(1975-1991)$

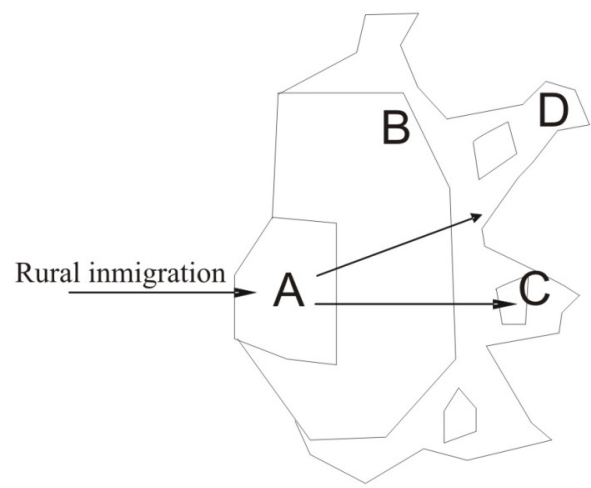

URBAN STRUCTURE AND INDUSTRIAL CITY (II) $(1930-1975)$

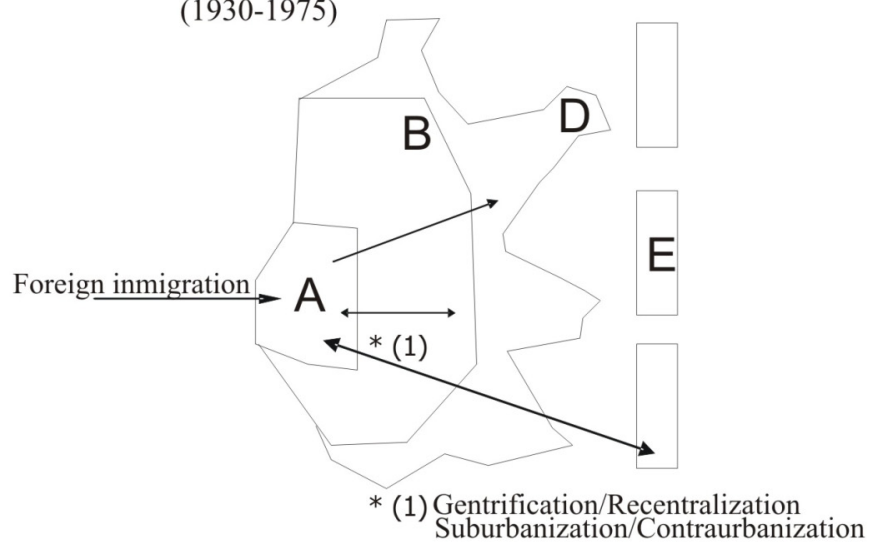

URBAN STRUCTURE AND POSTINDUSTRIAL CITY (II) $(1991-\ldots)$

Fig. (6). Processes of change and population mobility in the Spanish preindustrial city A: Preindustrial city; B: Ensanche of population; C: Sectors of informal city (Barraquismo); D: the Desarrollista city: peripheral quarters and housing states; E: suburban areas. Source: inhouse.

middle-class families to settle here, with the subsequent impoverishment of city life and social relations. This increase in land prices is one of the outcomes of speculative practices. Probably owing to scarce caution in special planning, new tourist modalities are particularly successful in recently rehabilitated centres, where there was plenty of unoccupied housing in bad state before initiating the process. In such conditions, speculation and the housing sector have found their ideal market (Fig. 8).

The spread of secondary housing -but also the abundance of unoccupied housing in recently rehabilitated quarters- is indicators of this situation. $25 \%$ of housing in the city within 


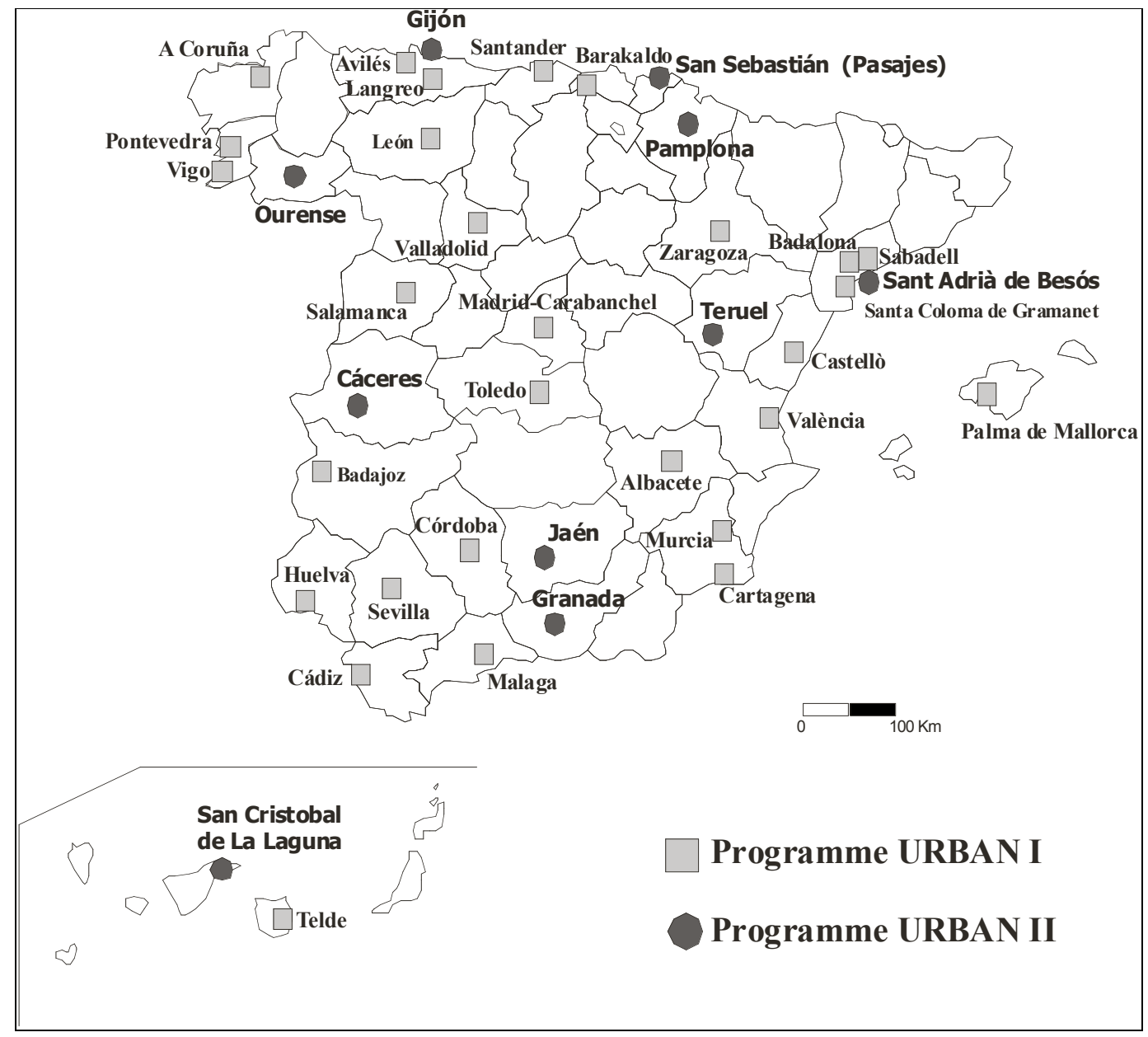

Fig. (7). Beneficiary cities of urban programmes source: self-made from European commission.

the walls in Palma de Mallorca was not occupied in 2001. A great deal of it is concentrated in the most decayed quarters, although another not inconsiderable part is located in the recently recovered sectors. In the latter, investors - most of them German- hold a part of the offer -so that it does not come out into the market- for speculative purposes, and another one is sold at prices above its real value (up to 6,000 Euros $/ \mathrm{m}^{2}$ ). In the city within the walls in Ibiza (Dalt Vila) declared World Heritage-, special planning puts an emphasis on residential tourism to finance housing rehabilitation (Table 3). A company is in charge of rehabilitating this housing in exchange of its use and occupation for a certain time [21]. During the last years, this company has had all the exploitation rights of such housing, which, usually ends up having a tourist and vacation use. If we look at Table 1, only a quarter of housing in Dalt Vila is primary housing. Little of it has a secondary use and most is unoccupied, although it is actually occupied during the summer. Out of the 624 people living in Dalt Vila, only about 200 are whole-year dwellers.

As in many other things, ideology is present in town planning and so it is possible to identify ideological differences in rehabilitation goals. Apparently, the most progressive ones defend interventionist estrategies with social and heritage recovery goals. The most conservative ones go for a kind of business-city where building of sceneries and economic exploitation prevail. However, revitalization understood as business -massive tourism in a museumized space, secondary residence, franchise shops, etc.- actually seems to have been accepted by proggresives and conservatives. The new permanent or ocassional dweller -gentrification?- demands modern housing but with a historicist-style architecture. The postmodernist vision is flooding every new building. The result may be a new, more liberal, more unreal (as scenery), more elitist and more recreational city.

To sum up, the extreme commercial exploitation of the city has rebuilt it according to the tastes of a new social class which has chosen to live a part of the year in a historic quarter. As in any other part of the current city, franchise shops owned by multinational companies also replace traditional retail shops in historic centres, and traditional landscapes are flooded with the most varied nowhere elements. All of this breaks the image of a historic city with originally differenciated traces, which struggles with physical-social deterioration and economic revitalization. Particularly in those places more influenced by tourist activities, the result is a historic city spreading many images, some of them real and many unreal. In order to do this, the historic centre uses without complexes every tool of competition and marketing on an urban and intraurban scale -i.e. a global city with all its consequences. 

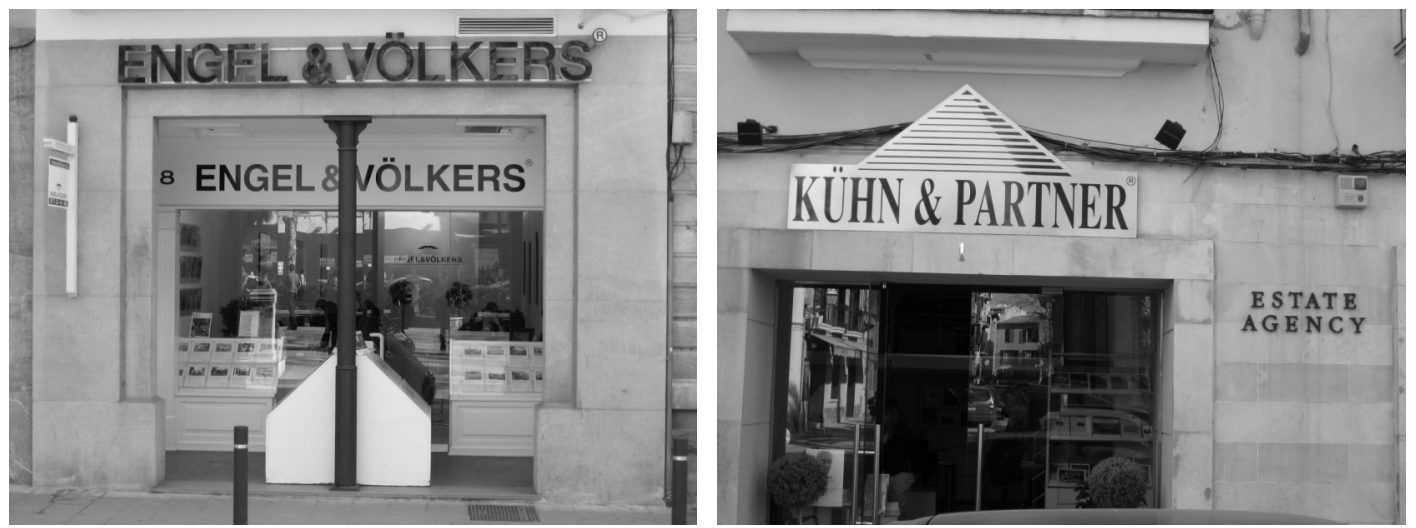

Fig. (8). The new production agents of the historic city in tourist-residential specialized areas. Source: self-made.

Table 3. Housing Types in Historic Centres of Cities Declared World Heritage in 2001. Distribution Expressed in Percentage

\begin{tabular}{|l|r|r|r|r|r|}
\hline & \multicolumn{1}{|c|}{ Ávila } & Alcalá H. & Cáceres & Córdoba & Cuenca \\
\hline \hline Conventional Primary Housing & 56.99 & 70.02 & 66.82 & 72.92 & 50.05 \\
\hline Secondary Housing & 15.88 & 6.32 & 20.01 & 3.05 \\
\hline Unoccupied Housing & 20.97 & 21.34 & 6.33 & 17.87 & 3.50 \\
\hline Other Type & 6.17 & 2.32 & 0.00 \\
\hline
\end{tabular}

\begin{tabular}{|c|c|c|c|c|c|}
\hline Ibiza & La Laguna & Salamanca & Santiago & Segovia & Toledo \\
\hline 28.76 & 63.11 & 63.52 & 68.15 & 62.56 & 62.51 \\
\hline 0.48 & 20.12 & 26.65 & 14.67 & 12.95 & 11.10 \\
\hline 70.29 & 14.13 & 9.78 & 17.16 & 17.21 & 25.70 \\
\hline 0.48 & 2.64 & 0.06 & 0.03 & 7.28 & 0.60 \\
\hline
\end{tabular}

Source: self-made from the 2001 population and housing census.

\section{NEW LANDSCAPES AND RENEWED CONFLICTS: THE PRESENCE OF FOREIGN POPULATION IN THE HISTORIC CITY}

We have already seen how the historic city fully shares the behaviours and dynamics of the global city. And immigration is the demographic phenomenon which best shows the belonging of this city area to a global system. The distribution of foreign population is directly related to the development level, but it is in cities where the effect of immigration on the territory and the landscape can be best perceived [22].

An unfinished rehabilitation process, areas where no intervention has been carried out or waiting for it due to speculation and failures of town planning itself -all of these factors explain the existence of deteriorated areas in the historic centres of Spanish cities. Thus, many historic quarters already recovered border on others with a high heritage value but also decayed and therefore located outside the tourist circuits and the property market: authentic "redlight districts" dwelled by vulnerable social groups and informal economic activities (drugs, prostitution, etc.). Although territorially small and socially beaten, these quarters can still be found in cities such as Vigo (Casco Vello), A Coruña (Papagayo), Ibiza (sa Penya), Palma (sa Guerreria), Valencia (Velluters), etc.
Cheap housing and more chances to hide it change these areas into the main entrance door for foreign immigrants. Meanwhile, rehabilitated areas are an appealing settlement space for higher-level inhabitants. As a result, shantytowns and gentrification occur simultaneously in a limited space, both in historic quarters outside the city walls -Raval: old poor quarter in Barcelona, now a vital part of its historic centre- and within the city walls -sa Guerreria in Palma: where the first 19th-century industrialization originated. This situation, which is not new in Spain nor original from the country- creates a fragmented historic city.

Foreigners' concentration in such quarters is quite common in the Spanish city. For instance, Madrid's Zona Centro district (Central Area) had the highest representation of foreigners in the whole district in 2006 (27.97\% of a population of 40,763). In Barcelona, relative significance is even higher. The 40,952 foreigners living in Ciutat Vella represent $38.5 \%$ of its total population. And in just one year this number rose in the district by almost 3,000 new foreign residents (Table 4).

Although ethnic diversity is generally predominant, there are some cases of guettization of some nationalities. In the case of Madrid, Ecuadorians represent $17.87 \%$ of the Zona Centro district and make up over $20 \%$ of all foreigners registered in the Embajadores district. On the other hand, although Pakistanis are predominant in Barcelona (15.57\%), 
Table 4. Historic Centres of Barcelona and Madrid. Foreign Nationalities with a Higher Representation Compared to the Whole Non-Spanish Population in 2006

\begin{tabular}{|c|c|c|c|}
\hline Barceloneta & Parc & Gótic & Raval \\
\hline \hline $14.60 \%$ Morocco & $14.80 \%$ Morocco & $9.54 \%$ Italy & $22.14 \%$ Pakistan \\
\hline
\end{tabular}

\begin{tabular}{|c|c|c|c|c|c|}
\hline Palacio & Embajadores & Cortes & Justicia & Universidad & Sol \\
\hline \hline $17.17 \%$ Ecuador & $20.26 \%$ Ecuador & $14.38 \%$ Ecuador & $11.62 \%$ Ecuador & $17.92 \%$ Ecuador & $16.89 \%$ Ecuador \\
\hline
\end{tabular}

origins are more diversified here: from the presence of Italians in one of the most revitalized city quarters -probably due to gentrification- to the existence of a quarter so culturally diverse as the Raval (old red-light district). In the latter, $47.2 \%$ of the population is of foreign origin.

Fig. (9) shows some of the analyzed aspects. The multifactorial causes which help explain the high foreign presence in the Ciutat Vella district, in Barcelona, may be extrapolated to other territories -considering local characteristics. For decades, the less administrative and tourist part of the historic centre in Barcelona has been undergoing a process of physical, social and functional deterioration. The arrival of foreign population with few economic resources looking for cheap housing may have contributed to the flight of the native population -which was already falling dramatically- as well as to the occupation of empty housing. As the number of foreigners arriving is higher than the number of Spanish residents leaving this area, its demographic density rose significantly. This process results in the deterioration of quarters which -due to their own physical-functional conditions- were already in crisis decades ago. According to Aramburu [23], the deterioration began before foreigners' arrival and therefore they are not the cause of the crisis.
In short, in spite of all the efforts made to favor gentrification, foreign immigration is the main responsible for the "repopulation" of historic centres. They concentrate the highest percentage of foreigners and are host to the most important ethnic diversity in the Spanish city (Figs. 10, 11). We all can observe every day how ethnic shops or international restaurants thrive in quarters which were losing economic activity until a few years ago. Likely, the high occupation of public spaces by some nationalities (squares, parks, gardens...) is not only enriching the urban landscape but also promoting the use and function of some places which were neglected until recently. It can be concluded that while the rehabilitated historic city is being dominated by franchise shops and a globalized economy, a new kind of retail business is being reborn -also mainly international owing to globalization.

\section{CONCLUSIONS}

In Spain, the recovery of the historic city has been characterized by the intensification of all urban transformation processes [17]. Therefore, the historic centres of our cities share fully the behaviours and dynamics of the global city without leaving aside their local special features. On the one hand, the Spanish city is less dense inside but its residential scattered expansion has not ruined the inner city. Presently, a development parallel to counterurbanization and

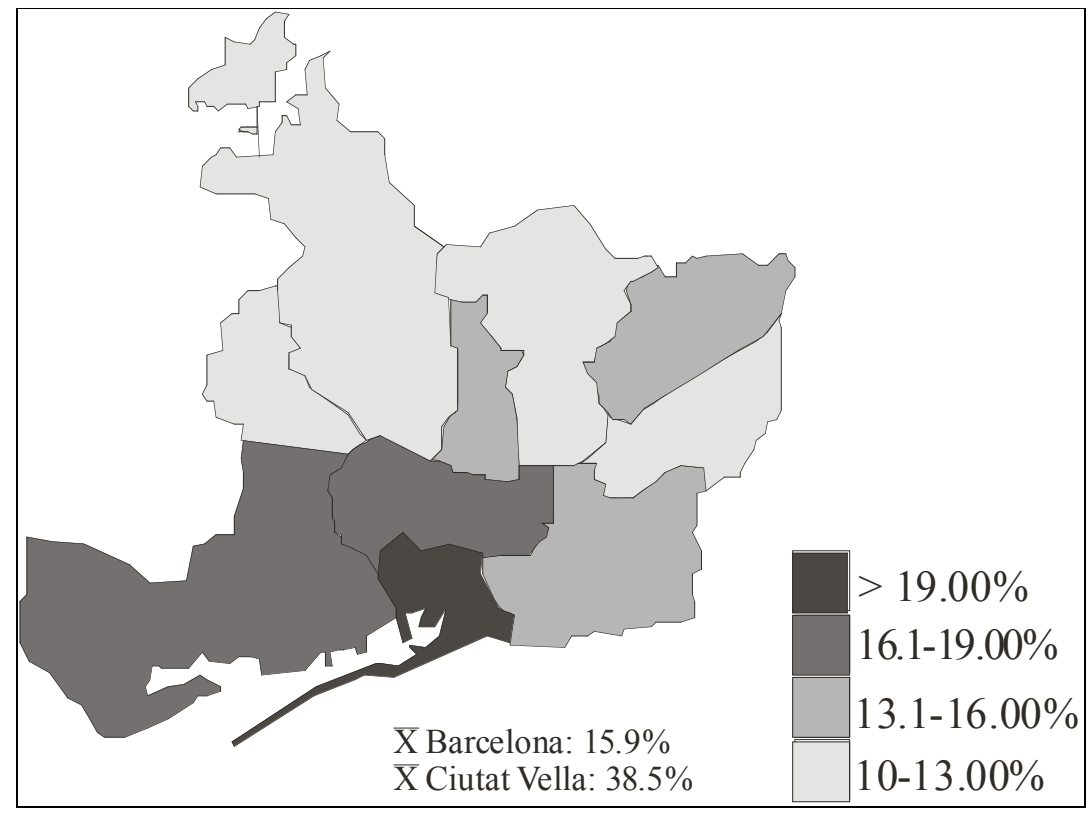

Fig. (9). Foreign population per Urban districts, Barcelona, 2006. Source: self-made from statistics of Barcelona's town council. 

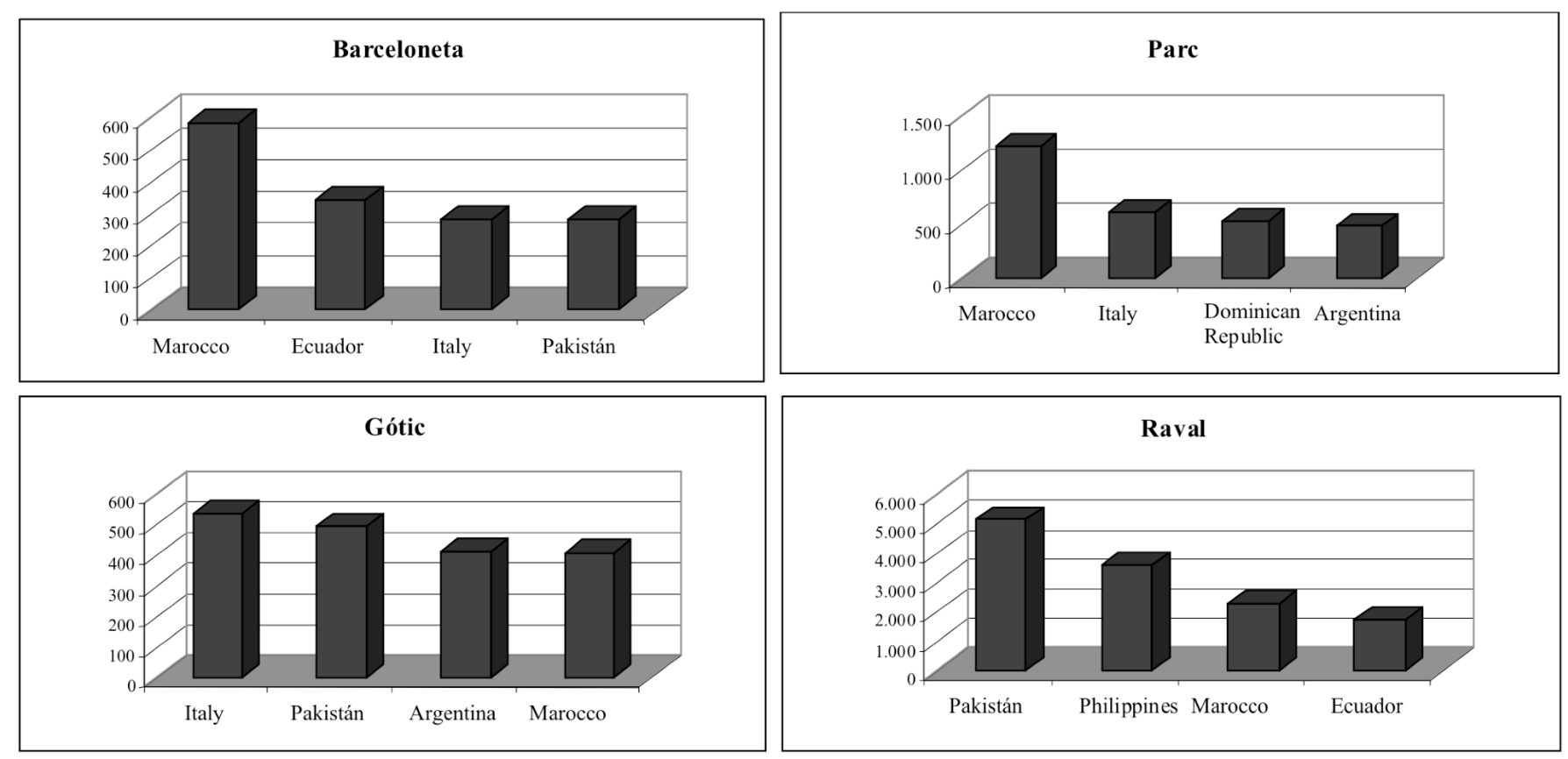

Fig. (10). The four most numerous nationalities in each quarter of the Ciutat Vella district, in Barcelona, year 2006. Classified by number of people. Source: self-made from statistics of Barcelona's town council.

gentrification is taking place in many historical cities. For different reasons, historic centres have been able to slow down the fall in population and some even show positive dynamics. On the other hand, there still coexist quarters in different preservation conditions in a good deal of historic centres, dwelled by social groups in different economic conditions. In such cases, preserved areas with a recognized heritage value can be clearly distinguished -due both to its urban centrality and to its more recent gentrification- from decayed quarters now reoccupied by foreign immigrants.

The maturing of the town planning system has played a leading role in the restoration of historic centres. Rehabilitation measures implemented since the 80 's have produced positive results. Mainly, historic centres have entered the new century as spaces highly charged with symbolism and quality. The biggest successes have been attained in the protection of heritage, the settlement of the local administration, the rehabilitation of singular buildings, etc. Some of the most important doubts rise about the role of "the public" in a city where private uses of land are rising and mixed (public-private) town planning is given top priority. In this sense, we can find two assessments. On the one hand, planning has produced interesting results in implementing measures to improve urban space and in providing public equipment, but these results have been inadequate as regards the shortage of green areas, the inappropriate classification of such areas and the poor investment in public housing. Madrid's Zona Centro district (523.73 Ha; 149,718 inhabitants in 2006) has $35.15 \mathrm{Ha}$ of green areas and gardens. In 2005, 209 public housing building and rehabilitation initiatives were put into effect and 845 were completely finished. With 4.5 million Euros, Ciutat vella is the district with the highest investment in this kind of initiatives. On the other hand, public administrations are relieved of many of their competences and obligations by the private sector. Three examples to illustrate this: the control over the land market by the property sector -including the debated preference for building underground car parks of private initiative in the historic framework; the building of new urban fabric on private or public-owned property rarely used for open spaces or public housing-; the preference for strategic planning, with an increasing importance of private companies. Without the necessary public control, this kind of planning can wrongly replace urban planning. Madrid's Town Council has recently focused on drawing up strategic plans for its quarters. The Plan Estratégico del Centro 2005-2008 (Strategic Plan for the Centre) has been passed for the pre-industrial city.

The priority so many times given to economic variables and widespread speculative practices cause that plans frequently look like façade recovery projects with an aim to creating an appropriate scenery for massive consumption (Fig. 12). This explains the abuse of a planning based on extraordinary actions - which has not been able to intervene looking at historic centres as a whole- and the role given to agents alien to their urban reality in the implementation of plans. For instance, it is still common that whole blocks are demolished to open new streets which are more accesible and comfort for traffic, walking and business; the new construction erected on the old pre-industrial plots of land is usually a very poor imitation of Medieval styles through the usual building of coloured façades; free and open spaces among blocks are eliminated to refill them later with constructions, etc. [9]. And all of this to promote the arrival of a new well-off class which is investing in historic centres for speculative purposes.

The Spanish immigration wave -having historic centres as its main residential destination in the city- has led to deeper exclusion and social segregation processes. The different administrations try to manage to finance costly monuments which contribute to create an image, a 

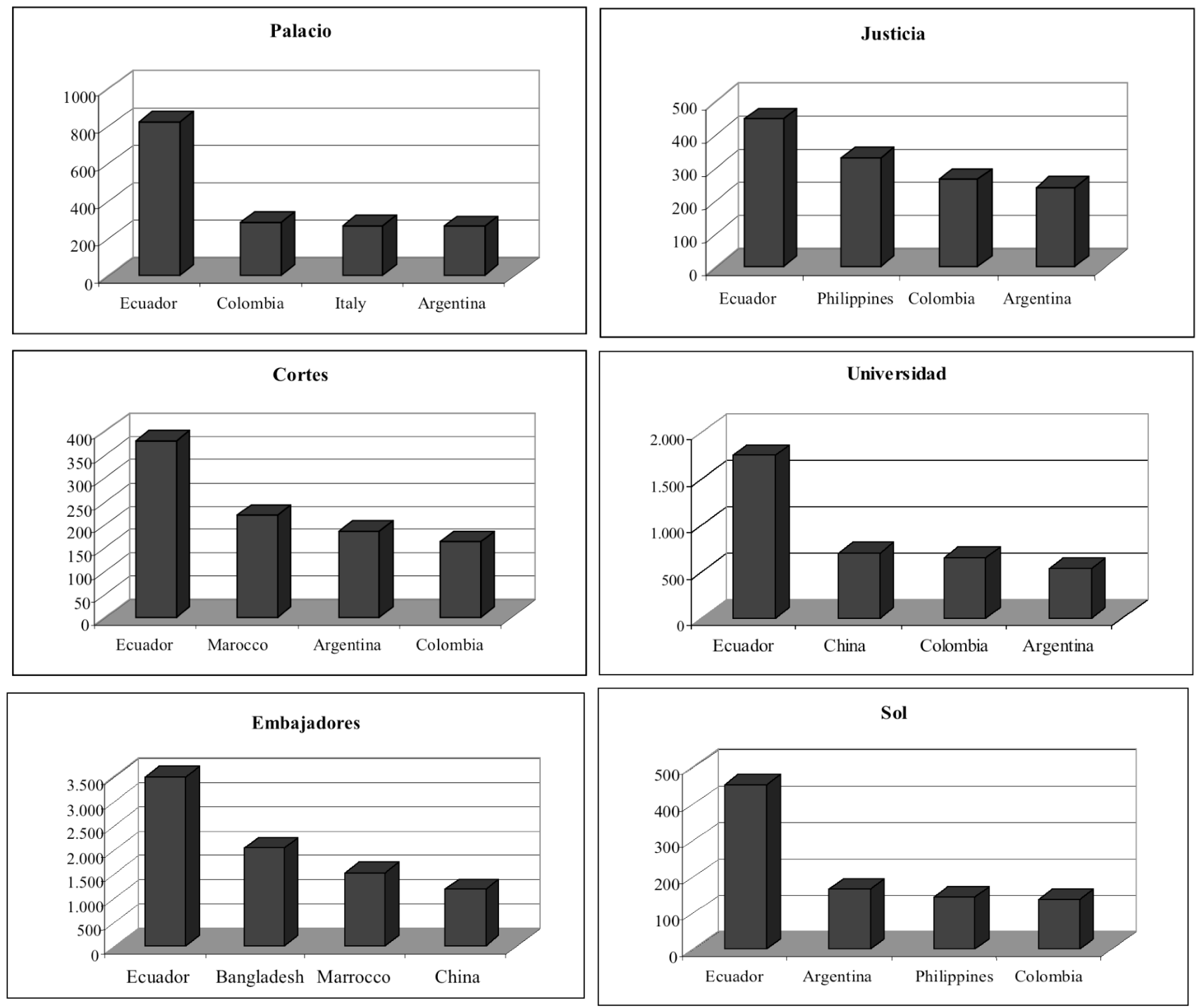

Fig. (11). The four most numerous nationalities in each quarter of the Zona Centro district, in Madrid, year 2006. Classified by number of people. Source: self-made from statistics of Madrid's town council.
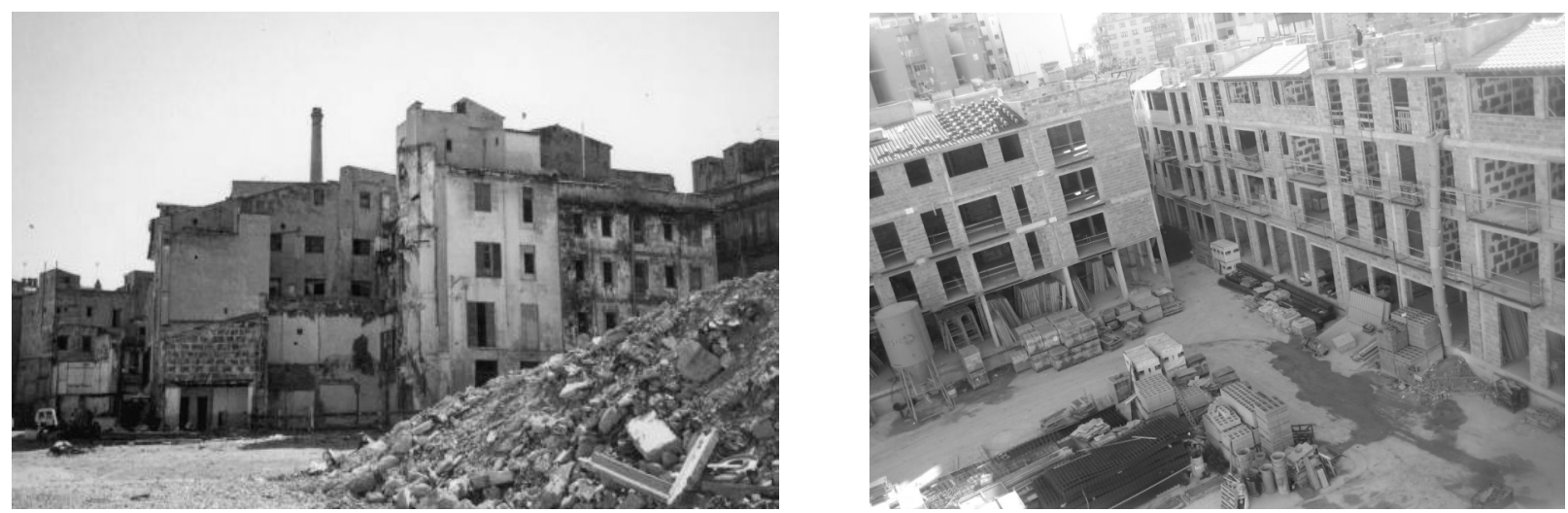

Fig. (12). New Urban Fabric in Sa Gerreria (Historic Centre in Palma): 1. Unoccupied Buildings in Ruins (2002), 2. Demolition and Rebuilding ex novo with Internal Public Square on an Underground Car Park (2006). Source: Self-Made.

promotionable product. However, they are not able to implement all-embracing social or housing policies which boost social or public-housing renting both for middle classes and new foreign-origin residents, both responsible for the present dynamism and diversity of historic centres.

\section{ACKNOWLEDGEMENTS}

The research on which this work is based has been financed with the research project of the Department of Research of the Ministry of Education and Science of Spain 
entitled: "La funcionalización turística de las Islas Baleares (1955-2000): adaptación territorial y crisis ecológica del archipiélago" (SEJ2006-07256/GEOG).

\section{REFERENCES}

[1] Amendola G. La Ciudad Postmoderna. Madrid: Celeste 2000.

[2] Hall P. El impacto de las nuevas tecnologías sobre los cambios urbanos y regionales. In: Metrópolis, territorio y crisis. Madrid: Asamblea de Madrid 1985; pp. 62-77.

[3] Borja J, Castells M. Local y global. La gestión de las ciudades en la era de la información. Madrid: Taurus 1999.

[4] Gomez J. Urbanismo e ingeniería en el siglo XIX. Reforma interior de las ciudades y movilidad. Madrid: Real Academia de Ingeniería 2006.

[5] De Terán, F. Historia del urbanismo en España III. Siglos XIX y XX. Madrid: Cátedra 1999.

[6] Capel H. La morfología de las ciudades. Sociedad, cultura y paisaje urbano. Barcelona: Ediciones del Serbal 2002.

[7] Trapero JJ. La práctica del planeamiento urbanístico en España. In: Moyá L, Ed. La práctica del planeamiento urbanístico. Madrid: Síntesis 1994; pp. 19-38.

[8] Mazón T. Introducción a la planificación urbana. Alicante: Aguaclara 1997.

[9] Quirós F, Tomé S. El proceso de urbanización: las ciudades. In: Gil A, Gómez J, Eds. Geografía de España. Barcelona: Ariel 2001; pp. 251-74.

[10] Cort C. Murcia Un ejemplo sencillo de trazado urbano. Madrid: Sucesores de Rivadeneyra 1932.

[11] Gabrielli B. Presente y futuro de la Rehabilitación como disciplina urbanística. In: II Encuentros Internacionales sobre Rehabilitación Urbana. Vitoria: Ayuntamiento de Vitoria-Gasteiz 1984; pp. 9-18.

[12] Ureña JMª . Teoría y práctica urbanística. In: L. López (Coord.), El planeamiento urbano y estratégico: II Jornadas de Estudio y Debate Urbanos. León: Universidad de León 1997; pp. 13-24.

[13] Troitiño MÁ. La dinámica de las ciudades y los retos del planeamiento urbanístico. In: L. López (Coord.), El planeamiento urbano y estratégico: II Jornadas de Estudio y Debate Urbanos. León: Universidad de León 1997; pp. 25-40.

[14] González JM. De la renovación urbana a las políticas de rehabilitación. El caso del casco histórico de Palma. II: 1943-2000. In: Blázquez M, Cors M, González JM, Seguí M, Eds. Geografía y territorio. El papel del geógrafo en la escala local. Palma de Mallorca: Universitat de les Illes Balears 2001; pp. 155-64.

[15] Macleod G, Ward K. Spaces of utopia and dystopia: landscaping the contemporary city. Geografiska Annaler 2002; 84B (3-4): 15370 .

[16] González, JM. Urban planning system in contemporary Spain. European Plann Stud 2007; 15(1): 29-50.

[17] Lois RC. Process of urban transformation in the historical cities in Spain. In: Pacione $\mathrm{M}$, Ed. Changing Cities. International Perspectives. Glasgow: IGU Urban Commission and Strathclyde University Publishing 2004; pp. 161-72.

[18] Troitiño MÁ. Turismo y desarrollo sostenible en ciudades históricas. Eria 1998; 47: 211-28.

[19] Brandis D, Del Río I. Turismo y medio ambiente urbano. Las experiencias de Ávila, Toledo y Salamaca. In: García JS, Troitiño MÁ, Eds. Vivir las ciudades históricas: recuperación integrada y dinámica funcional. Cuenca: Universidad de Castilla-La Mancha 1998; pp. 155-82.

[20] Santos XM, Lois RC, Eds. Desenvolvemento turístico sustentable en cidades históricas. Santiago: Concello de Santiago and Concello de Lugo 2005.

[21] González JM, Santos XM. Historical Cities and Tourism in Spain. In: Murayama Y, Du G, Eds. Cities in Global Perspective. Diversity and Transition Tokyo: IGU Urban Comission and Rikkyo University 2005; pp. 364-76.

[22] González JM, Somoza J. Territoire et inmigration en Espagne. Une étude de cas en Palma de Mallorca et León. Available from: http//: www.cybergeo.eu/index2440.html [Cybergeo 2004; 274: 1-20].

[23] Aramburu M. El mito de la huida autóctona. El caso de Ciutat Vella. Scripta Nova, Barcelona, Universidad de Barcelona 2001; 94(63): 1-11. Available from: http//:www.ub.es/geocrit/sn-9463.htm 